\title{
KEJADIAN DEPRESI DAN BUNUH DIRI PADA PENDERITA TOKSOPLASMOSIS
}

\author{
Samuel Gunawan Hutajulu ${ }^{1}$, Margaretha Carolina Hutajulu ${ }^{2}$ \\ Fakultas Kedokteran, Universitas Lampung \\ Program Studi Ilmu Keperawatan, STIKES Medistra Bekasi \\ * Samuel.kun97@gmail.com
}

\begin{abstract}
ABSTRAK
Infeksi parasit Toxoplasma gondii telah menjangkiti hampir seluruh penduduk di dunia. Gejala toksoplasmosis yang muncul pada individu beresiko seperti bayi, ibu hamil dan penderita imunokompromais ternyata dapat muncul juga pada individu imunokompeten. Ookista yang menimbulkan toksoplasmosis kronis di otak, mampu memengaruhi sistem saraf dan kejiwaan penderitanya. Banyak bukti yang menunjukkan hubungan antara munculnya afek depresi pada individu dengan peningkatan serum anti toksoplasma. Depresi yang berkepanjangan tanpa intervensi tenaga medis, baik terapi farmakologi maupun terapi non-farmakologi memunculkan pikiran bunuh diri pada penderita. Tujuan penelitian ini untuk menguraikan dampak dari penyakit toksoplasmosis yang tidak ditangani sehingga memunculkan berbagai macam gangguan psikiatri khususnya depresi dan bunuh diri. Penelitian ini merupakan hasil dari penelaahan pustaka dengan metode pencarian literatur yang dilakukan di internet dan buku teks berdasarkan pertanyaan mengenai patofisiologi penyakit toksoplasmosis yang terjadi dalam struktur anatomi sistem saraf pusat-perifer dan jalur neurotransmitter sehingga berakibat pada depresi dan ingin bunuh diri. Sumber pustaka terbaru dalam jangka waktu 15 tahun terakhir berjumlah 27 buah. Sebagai kesimpulan didapatkan gangguan keseimbangan neurotransmitter dopamin, serotonin dan glutamat serta perubahan pada kerusakan sel glial, amigdala dan korteks prefrontal yang menyebabkan perubahan suasana hati depresif pada penderita toksoplasmosis kronis.
\end{abstract}

Kata kunci : bunuh diri, depresi, inflamasi, neurotransmiter, toksoplasmosis

\section{EVENT OF DEPRESSION AND SUICIDE IN PEOPLE WITH TOXOPLASMOSIS}

\begin{abstract}
The parasitic infection of Toxoplasma gondii has infected almost population in the world. The fact that toxoplasmosis arises in at-risk persons such as infants, pregnant women and immunocompromised patients can also appear in immunocompetent individuals. Oocysts causes' chronic toxoplasmosis in the brain, can affect the patient's nervous system and psychiatric. There is a lot of evidence shows the relationship between emergence of depression's affect in person with an increase of serum antitoxoplasma. Prolonged depression without intervention from medical personnel, both pharmacological therapy and non-pharmacological therapy, raises thoughts of suicide in the patients. The purpose of this study is to describe the impact of toxoplasmosis which is not handled up so as bring up variety of psychiatric problems specifically depression and suicide. This paper is the result of a literature review using a literature search method on the internet and textbook conduction by questions about the pathophysiology of the disease that occurs in the anatomy of the centralperipheral nervous system and neurotransmitters that cause depression and commit to suicide. The latest sources of literature in the last 15 years replacement of 27 sources. In conclusion, disorders of the neurotransmitter dopamine, serotonin and glutamate balance and changes in glial cell, amygdala and prefrontal cortex may cause changes in patients mood with chronic toxoplasmosis.
\end{abstract}

Keywords : suicide, depression, inflammation, neurotransmitter, toxoplasmosis 


\section{PENDAHULUAN}

Depresi merupakan salah satu kelainan afektif yang paling umum dan mampu menyebabkan penderitaan kronis secara global bagi individu. Gejala yang timbul mulai dari perubahan mood, hilangnya minat dan hobi, gangguan fungsi kognitif, gangguan tidur hingga makan secara signifikan mampu meningkatkan angka morbiditas dan mortalitas. Penelitian akhirakhir ini, didapatkan prevalensi depresi tinggi pada pasien yang memiliki penyakit infeksi seperti parasitToxoplasma gondii (Hsu, Groer \& Beckie, 2014). Hal ini sesuai dengan hipotesis Inflammation-associated depression dimana pengaruh inflamasi akibat mikroba patogen mampu mengubah susunan neurotransmitter otak dan menimbulkan gejala depresi serta ingin bunuh diri (Müller \& Schwarz, 2007).

Lebih dari 40.000 penduduk Amerika Serikat meninggal dunia akibat bunuh diri. Penyebab bunuh diri ini sangat kompleks dan tidak dapat dimengerti sepenuhnya. Faktor utama adalah pasien yang telah didiagnosis dengan kelainan psikiatrik seperti depresi berat, kepribadian bipolar ataupun skizofrenia. Selain faktor tersebut, hal lain yang mampu meningkatkan resiko bunuh diri adalah kesulitan hidup, tipe kepribadian yang sulit seperti impulsif, faktor genetik serta penggunaan narkoba (Dickerson et al., 2017). Terdapat bukti yang mengindikasikan hubungan proses inflamasi akibat infeksi Toxoplasma gondii terhadap peningkatan distribusi perilaku bunuh diri (Pjevac \& Pregelj, 2012).

Toksoplasmosis merupakan kejadian infeksi oleh parasit intraseluler, Toxoplasma gondii, parasit agen infeksi yang paling sering menginfeksi manusia dengan gejala asimtomatik. Penularan parasit biasanya lewat makanan atau minuman yang terkontaminasi ookista, bisa juga dengan mengonsumsi daging yang mengandung kista jaringan. Pada beberapa individu, infeksi toksoplasmosis dapat menyerang nodus limfa, mata dan sistem saraf pusat termasuk menimbulkan sekuel psikiatrik. Banyak laporan mengenai kasus toksoplasmosis, yang ditandai dengan peningkatan titer antibodi anti- T.gondii, dengan gangguan-gangguan psikiatrik pada individu seperti munculnya gejala depresi, timbulnya skizofrenia hingga meningkatnya angka bunuh diri pada wanita dan pria di Eropa (Alvarado-Esquivel et al., 2013).

T. gondii memiliki mekanisme yang kompleks saat menginfeksi otak. Setelah berhasil menembus sawar darah otak, parasitakan menginvasi seluruh sel otak termasuk astrosit dan neuron dimana akan terbentuk kista. $T$. gondii yang merusak sistem saraf pusat (SSP) tidak hanya menimbulkan defek neurologis organik namun juga kelainan psikiatrik pada beberapa individu. Untuk menimbulkan gejala ini dibutuhkan berbagai reaksi imunologis dan reaktivasi kista sehingga menimbulkan berbagai gangguan perilaku (Fekadu, Shibre \& Cleare, 2010). Pada hewan coba didapatkan perubahan perilaku lebih agresif setelah diinfeksi oleh protozoa $T$. gondii(Carruthers \& Suzuki, 2007).

Adanya tragedi bunuh diri merupakan fenomena penyakit mental dan perilaku yang tidak dapat dibiarkan begitu saja, karena keberadaanya mempengaruhi banyak sektor publik dan kualitas hidup(Fekadu, Shibre dan Cleare, 2010). Demikian pula dengan depresi akibat toksoplasmosis, praktisi kesehatan harus memikirkan kemungkinan terjadinya infeksi sebagai penyebab penyakit kejiwaan selain faktor imbalance neurotransmitter dan psikologis. Selain itu dibutuhkan pedoman yang cepat dan tepat untuk mengatasi depresi berat agar tidak berlarut-larut dan menimbulkan pikiran ingin bunuh diri (Hsu, Groer dan Beckie, 2014).

Penderita toksoplasmosis kronis yang sering dianggap asimtomatik, ternyata menimbulkan gejala psikiatris berupa depresi. Depresi yang tidak tertangani mampu memunculkan pikiran, percobaan dan hasil bunuh diri sehingga angka mortalitas dan morbiditas meningkat. Penelitian ini bertujuan untuk mengetahui pengaruh infeksi $T$. gondii terhadap timbulnya gejala depresi dan bunuh diri serta penanganan secara medis dan psikologis. Jenis penelitian ini adalah tinjauan pustaka dimana hasil dan pembahasan didasarkan pada sumber ilmiah yang valid dan akurat.

\section{METODE}

Penelitian ini merupakan studi literature review, di mana peneliti mencari, menggabungkan inti sari serta menganalisis fakta dari beberapa sumber ilmiah yang akurat 
dan valid, yang mendukung dan menjadi bukti kejadian depresi dan bunuh diri pada penderita infeksi toksoplasmosis. Rumusan masalah disusun berdasarkan prinsip P-I-C-O (Patient $=$ penderita toksoplasmosis, Intervention, Comparison $=$ placebo, Output $=$ timbulnya kejadian depresi dan bunuh diri) yaitu "Bagaimana pengaruh toksoplasmosis terhadap timbulnya depresi dan bunuh diri pada individu?" Pencarian untuk jurnal ilmiah menggunakan situs jejaring http://ncbi.nlm.nih.gov, http://cochranelibrary.com dan http://scholar.google.co.id. Kemudian dimasukkan kata kunci pada kolom pencarian menurut PICO yang telah ada untuk menampilkan hasil seluruh jurnal yang berhubungan. Pada opsi penyaring, diaktifkan pencarian menurut tahun (maksimal 15 tahun terakhir) dan subyek (manusia).Pada akhirnya, sumber ilmiah yang digunakan berupa textbook dan jurnal ilmiah yang berjumlah 27 buah. Telaah kritis menggunakan asas V-I-A (Validity, Important, Applicability) untuk menentukan kesesuaian antara sumber yang didapatkan dengan pertanyaan awal. Setelahnya dapat ditarik jawaban yang bersumber dari hasil dan pembahasan dalam sumber ilmiah.

\section{HASIL}

\section{Toksoplasmosis}

Toxoplasma dalam bahasa Yunani berarti berbentuk seperti panah, parasit ini pertama kali ditemukan pada tahun 1908 menginfeksi hewan pengerat Ctenodactylus gund. Taksonomi dari parasit ini, yaitu Kingdom: Animalia, Sub Kingdom: Protozoa, Filum: Apicomplexa, Kelas: Sporozoasida, Sub Kelas: coccidiasina, Ordo: Eucoccidiorida, Sub Ordo: Eimeriorina, Famili: Sarcocystidae, Genus: Toxoplasma, Spesies: Toxoplasma gondii. (Hadidjaja \& Margono, 2013)

Siklus hidup $T$. gondii terbagi menjadi siklus seksual dan siklus aseksual. Tahap seksual parasit hanya terjadi di dalam tubuh inang definitif yaitu kucing. Kista dalam jaringan yang tertelan oleh kucing kemudian dilarutkan oleh enzim proteolitik dan melepaskan bradizoit ke dalam usus halus. Kemudian terjadi pembuahan dan terbentuklah gamogoni. Gamogoni akan terkumpul dalam ileum dan terbentuklah dinding kista ookista. Ookista kemudian dikeluarkan bersamaan dengan fese kucing (Dubey, 2009)

Ookista mengandung delapan Sporozoit yang dibungkus oleh 2 sporokista. Sporokista (sekitar $8 \times 6 \mu \mathrm{m}$ ) akan berkembang terus hingga menjadi sporogoni. Sporozoit akan keluar dan melanjutkan fase aseksual bila sudah tertelan oleh inang perantara, yaitu hewan-hewan berdarah hangat seperti manusia, kambing dan sapi. Sporozoit secara langsung akan menginvasi sel fagosit makrofag dan dibawa oleh pembuluh limfatik memasuki berbagai organ dan berkembang secara cepat menjadi merozoit pre-kistik melalui multiplikasi endodiogeni. Merozoit akan bertransformasi membentuk takizoit yang aktif membelah dan bradizoit dengan pembelahan lebih lambat namun menyebabkan infeksi kronik. (Roberts \&Janovy Jr, 2009).

Gejala yang ditimbulkan toksoplasmosis terlihat seperti simtomatik dan asimtomatik. Gejala simtomatik terbagi menjadi tiga, yaitu pada fase akut, fase sub-akut, dan fase kronik. Pada infeksi akut di usus, nodus limfa dan hepar dengan gejala pembengkakan nodus limfa aksila, supraklavikula dan inguinal, demam, sakit kepala, mialgia, anemia, dan komplikasi pada paru-paru akibat flu dan sindrom infeksi nafas lain. Selanjutnya, tahap sub-akut terjadi kerusakan pada paru-paru, hepar, otak dan mata. Pada individu imunokompromais lesi mungkin melibatkan sistem saraf pusat dan organ lain seperti jantung. Takizoit yang terperangkap dalam mata dan membentuk kista bradizoit dapat menyebabkan titik buta (blind spot) dan infeksi area macular pusat, gejala ini menjadi salah satu tanda infeksi kronis dan menetap. (Hadidjaja \&Margono, 2013)

Oleh karena infeksi yang asimtomatik, diagnosis toksoplasmosis spesifik pada manusia harus didasarkan oleh satu atau lebih pemeriksaan penunjang, antara lain: (Roberts \& Janovy Jr, 2009)(a) Diagnosis dengan mikroskop cahaya saja kurang sensitif dan akurat, diagnosis untuk menemukan kista jaringan memerlukan pemeriksaan dengan mikroskop electron dan keahlian dari petugas (Liu et al., 2015)(b) Diagnosis dengan uji imunologis, memiliki nilai diagnostic $T$. gondii yang tinggi dengan jalan mendeteksi peningkatan $\operatorname{IgA}$, IgG dan IgM toksoplasma. 
(c) Diagnosis secara Genetik Molekular, memiliki sensitivitas, spesifisitas dan utilitas klinis yang paling tinggi dengan bahan pemeriksaan pungsi lumbal, cairan limfa ataupun lavase bronkopleural. (Hadidjaja \& Margono, 2013) (d) Diagnosis dengan Pemeriksaan Radiologi, hanya bermanfaat pada kejadian toksoplasmosis kongenital yang mengalami kalsifikasi intrakranial. (Kasper et al., 2015) (e) Isolasi Toxoplasma gondii pada hewan coba, biasanya dilakukan pada jaringan sisa aborsi, plasenta atau sisa tali pusar(Hadidjaja \& Margono, 2013).

Pirimetamin diyakini sebagai obat yang paling efektif bagi toksoplasmosis. Karena sifatnya yang merupakan asam folat antagonis, terapi disertai dengan asupan leucovorin. Lini kedua untuk terapi toksoplasmosis ialah Sulfadiazin dan Klindamisin yang diberikan apabila terdapat kontraindikasi berupa hipersensitivitas obat. Dosis pirimetamin dewasa yaitu 1 x $100 \mathrm{mg}$ dosis awal, diikuti $25-50 \mathrm{mg} / \mathrm{hari}$ atau sulfadiazine $500 \mathrm{mg}-1$ gram/ hari dengan leukovorin $5-25 \mathrm{mg} / \mathrm{mg}$ pirimetamin. Dosis anak-anak ialah 2 $\mathrm{mg} / \mathrm{kgBB}$ hari pertama diikuti $1 \mathrm{mg} / \mathrm{kgBB}$ atau sulfadiazin $50 \mathrm{mg} / \mathrm{kgBB}, 2$ kali per hari ditambah asam folat/leucovorin 7,5 mg/hari (Maldonado et al., 2017).

\section{Depresi \\ Menurut Diagnostic and Statistical Manual of Mental Disorder (DSM IV) kriteria kelainan depresi adalah periode merasakan kesedihan, tidak ada harapan dan keputusasaan yang dialami paling tidak selama dua minggu(Hsu, Groer \&Beckie, 2014). Depresi sendiri merupakan keadaan afek, selain elasi yang disertai dengan perubahan pada seluruh tingkat aktivitas dan banyak gejala sekunder yang mudah dipahami dengan perubahan itu(Maslim, 2013).}

Menurut Pedoman Penggolangan dan Diagnosis Gangguan Jiwa III (PPDGJ-III), terdapat gejala utama dan gejala penyerta dalam mendiagnosis dan mengklasifikasikan keadaan depresi. Gejala utama, antara lain: afek depresif, hilangnya minat dan kegembiraan, dan berkurangnya energi yang menuju meningkatnya keadaan mudah lelah (rasa sangat lelah sesudah sedikit bekerja) dan menurunnya aktivitas. Sedangkan gejala lainnya termasuk: konsentrasi dan perhatian yang kurang, harga diri dan kepercayaan berkurang, gagasan rasa bersalah dan tidak berguna, pandangan masa depan suram dan pesimistis, gagasan atau perbuatan membahayakan diri atau bunuh diri, tidur terganggu dan nafsu makan yang berkurang(Maslim, 2013).

Seseorang dikatakan mengalami episode depresi ringan bila memenuhi 2 dari 3 gejala utama, ditambah 2 gejala lainnya, berlangsung paling tidak dua minggu dengan sedikit kesulitan pekerjaan dan kegiatan sosial. Episode depresi sedang bila terdapat 2 dari 3 gejala utama, ditambah 3 gejala lainnya, berlangsung selama dua minggu dan menghadapi kesulitan besar saat kegiatan sosial, pekerjaan dan rumah tangga. Sedangkan episode depresi berat terjadi apabila terdapat 3 gejala utama dengan 4 gejala penyerta, kemungkinan terdapat agitasi ataupun retardasi psikomotor, lamanya dua minggu dan tidak mungkin bagi penderita untuk meneruskan kegiatan pekerjaan, sosial dan rumah tangga (Maslim, 2013).

Ada banyak sekali faktor yang dapat menyebabkan depresi, antara lain: (1)Faktor Fisik: a. Genetik, tidak semua orang dengan riwayat keluarga depresi bisa mengalami depresi lebih berpengaruh individu dengan gangguan bipolar, b.Susunan kimia otak dan tubuh, hormon noradrenalin. Norepinefrin dan serotonin merupakan dua neurotransmiter yang paling berkurang aktivitasnya pada keadaan depresi. Penemuan terbaru juga menemukan disfugsi jalur dopamine mesolimbik pada penderita depresi(Elvira \& Hadisukanto, 2014), c.Usia pada golongan remaja dan dewasa muda (18-44 tahun) oleh karena proses peralihan masa perkembangan, d.Gender, depresi dua kali lipat lebih banyak menyerang wanita disbanding pria, e.Gaya hidup termasuk makanan tidak sehat, kebiasaan tidur buruk dan tidak berolahraga, f. Penyakit medis, g.Efek samping terapi obat, h.Penggunaan obat-obatan terlarang, i.Kurangnya cahaya matahari, berhubungan dengan kejadian sessional affective disorder/SAD dimana hormone melatonin yang diproduksi oleh kelenjar pineal aktif menurut banyaknya cahaya matahari. (2)Faktor Psikologis: a.Kepribadian introvert dengan konsep diri dan pola pikir negatif dan pesimis, b.Pola pikir yang negatif terhadap diri sendiri, tidak mengakui kesuksesan dan berfokus pada 
kegagalan, c.Harga diri terhadap diri sendiri atau self-esteem yang rendah, d.Stres, seperti pengalaman bencana alam, perang, kematian, pertengkaran, perceraian serta mikrostresor aktivitas sehari-hari, e.Lingkungan keluarga, depresi terjadi pada anak-anak yang kehilangan orang tua, f.Penyakit jangka panjang atau kronis menyebabkan seseorang kehilangan energi dan membuat penderita dalam keadaan tidak berdaya.

Terapi yang diberikan pada penderita depresi terdiri dari, farmakoterapi, psikofarmakoterapi terfokus, terapi somatik, dan perubahan gaya hidup (Soleimani, Lapidus dan Iosifescu, 2011). Farmakoterapi sebagai lini pertama pada depresi yaitu selective serotonergic reuptake inhibitors/SSRIs serta serotonin and norepinephrine reuptake inhibitors/SNRIs misalnya Fluoxetin 1 x 20 mg ataupun Amitriptilin 1 x $25 \mathrm{mg}$ selama 4-6 minggu. Obat-obatan lain yang dapat digunakan seperti tricyclic antidepressant/TCA, monoamine oxidase inhibitors/MAOIs, noradrenergic dopamine reuptake inhibitor/NDRI, serotonin $2 A$ antagonist reuptake inhibitors/SARIs, serta noradrenergic and specific serotonin antidepressant(Hsu, Groer \& Beckie, 2014).

Psikoterapi untuk depresi terdiri dari CBT atau Cognitive Behavioral Therapy yang merupakan salah satu teknik relaksasi untuk menenangkan pikiran. Selain itu bisa digunakan behavioral therapy serta terapi interpersonal. Selain kedua terapi di atas bisa juga digunakan terapi somatik dengan metode Electroconvulsive therapy/ECT menggunakan stimulasi elektrik bilateral dan unilateral yang menginduksi kejang, kelemahannya dibutuhkan analgesik yang tepat dan resiko efek samping berupa amnesia. Terapi somatik lain termasuk transcranial magnetic stimulation/TMS, sebuah induksi depolarisasi non-invasif otak dengan lapang magnetic serta vagus nerve stimulation(Soleimani, Lapidus \&Iosifescu, 2011). Perubahan gaya hidup dan pengobatan alternatif untuk depresi termasuk aktivitas fisik dan suplemen diet seperti asam lemak omega 3, S-adenosyl methionine, St John's wort.

\section{Bunuh Diri}

Bunuh diri dapat diartikan sebagai kematian yang disebabkan oleh perlukaan diri sendiri dengan kehendak ingin mati. Bila keinginan untuk mengakhiri hidup tidak disertai dengan kematian oleh aksinya, hal ini dapat disebut sebagai percobaan bunuh diri (CDC, 2018)

Emile Durheim membagi macam-macam bunuh diri dan percobaan diri menjadi:(Maramis \& Maramis, 2009) (a.) Bunuh diri egoistik, yang terjadi pada individu yang tidak bisa berintegrasi dengan masyarakat. (b.) Bunuh diri altruistik, akibat individu yang merasa terikat pada tuntutan tradisi khusus seperti Harakiri di Jepang. (c.) Bunuh diri anomik, terjadi akibat adanya gangguan keseimbangan integrasi individu dengan norma-norma kelakuan yang ada di masyarakat.

Bunuh diri memilik beberapa faktor resiko dan faktor protektif. Bunuh diri merupakan hasil dari respon multipel terhadap pengaruh biologis, psikologis, interpersonal, lingkungan dan masyarakat yang saling berinteraksi. Faktor resiko bunuh diri, antara lain (Stone et al., 2017): (1)Keadaan individu: riwayat depresi dan penyakit mental lain, kondisi kesehatan tertentu, victimization dan perpetration serta faktor genetik. (2)Keadaan hubungan: konflik atau kekerasan dalam hubungan, riwayat keluarga yang bunuh diri, stres kerja dan masalah finansial. (3)Keadaan masyarakat: ketersediaan sarana bunuh diri, media yang tidak baik, stigma tentang penderita penyakit kejiwaan.

Adapun faktor-faktor protektif individu dari melakukan bunuh diri, ialah: mekanisme coping dan problem-solving yang efektif, hubungan yang kuat dan saling mendukung dengan teman, pasangan dan keluarga, ketersediaan pelayanan kesehatan mental yang berkualitas dan berkelanjutan serta berkurangnya akses terhadap sarana bunuh diri (Stone et al., 2017).

Besarnya resiko bunuh diri dapat dinilai dengan melihat tanda-tanda resiko berat dan tanda-tanda bahaya. Tanda-tanda resiko berat antara lain: keinginan mati yang sungguhsungguh (pernyataan ingin mati berulangulang), depresi dengan rasa salah dan dosa terhadap orang yang sudah meninggal, serta adanya psikosis impulsif yang curiga, ketakutan dan panik (Maramis \& Maramis, 2009). 
Tanda-tanda bahaya bunuh diri, antara lain: pernah melakukan percobaan bunuh diri (anggapan keliru tidak akan berbuat lagi), depresi akibat penyakit menahun, ketergantungan terhadap narkoba dan alkohol melemahkan kontrol dan mengubah impuls (Maramis \& Maramis, 2009).

Terapi yang dapat diberikan pada individu yang mencoba bunuh diri dapat berupa psikofarmaka seperti golongan benzodiazepine (Lorazepam 3 x 1mg, 2 minggu) ataupun antidepresan (Fluoxetin 1 x $20 \mathrm{mg}$ ). Terapi obat disertai dengan terapi non-farmakologi seperti psikoterapi suportif ataupun cognitive behavior therapy. Selain itu, perlu terapi khusus berdasarkan penyebab ingin bunuh diri. Pasien dengan gangguan kepribadian perlu dilakukan manipulasi lingkungan, sedangkan pasien skizofrenia letalitas tinggi merupakan tanda rawat inap jangka panjang. (Elvira \& Hadisukanto, 2014).

Pencegahan agar tidak timbul niat bunuh diri diperlukan untuk menekan angka kematian dan angka morbiditas rawat inap di rumah sakit jiwa. Hal-hal yang dapat dilakukan, antara lain: memperkuat dukungan finansial rumah tangga dan perumahan, meningkatkan akses dan pelayanan terhadap perawatan pasien ingin bunuh diri dengan asuransi kesehatan kejiwaan, menciptakan lingkungan yang protektif dengan mengubah stigma dan alcohol-use di masyarakat, menciptakan hubungan yang baik dengan ikut dalam program masyarakat, mengajarkan kemampuan coping dan problem solving melalui keluarga pada anak, identifikasi dan dukung orang-orang yang berisiko bunuh diri, mengurangi bahaya di masa depan melalui media yang aman tanpa konten suicidal (CDC, 2018).

\section{PEMBAHASAN}

\section{Peran neuroimunologi terhadap depresi dan bunuh diri}

Makrofag, sel dendritik dan mikroglia dalam otak menghasilkan sitokin dan mediator proinflamasi lainnya setelah mengenali pola molekular patogen yang berikatan dengan reseptor spesial yang disebut Toll-like receptors. Sitokin ini kemudian akan memberi sinyal kepada otak melewati tiga jalur: kebocoran infiltrasi atau kegagalan sawar darah otak, sinyal tak langsung lewat protein karier cytokine-specific yang mentransfer reseptor sitokin sel endotel, atau transmisi pesan imun dari perifer menuju otak lewat jalur neural saraf aferen (Hsu, Groer \&Beckie, 2014).

Patogen inflamasi dapat memicu respon imun innate dan adaptif. Sitokin yang disekresi oleh berbagai sel imun terstimulasi merespon berbagai tipe patogen infeksius. Respon imun bawaan berespon terhadap patogen infeksius menghasilkan produksi sitokin proinflamasi yang termasuk interleukin (IL-1, IL-6) dan Tumor Nekrosis Alfa (TNF- $\alpha$ ). Respon imun adaptif, memiliki dua tipe. Tipe pertama imunitas terhadap sitotoksisitas seluler dengan sekresi sitokin tipe 1 yaitu IFN- $\gamma$, IL-2. Imunitas tipe 2 berperan sebagai anti-inflamasi termasuk di dalamnya T-helper 2 (Th2) dan sekresi sitokin tipe 2 yaitu IL-4, IL-5, IL-13 (Hsu, Groer \& Beckie, 2014)

Penelitian menunjukkan bahwa perilaku depresi dan bunuh diri berkaitan dengan ketidakseimbangan respon imun dan metabolisme neurotransmitter monoamine. Neurotransmitter utama yang terpengaruh oleh proses inflamasi adalah serotonin dan dopamin (Hsu, Groer\& Beckie, 2014)

Sistem serotonergik dengan aktivasi indoleamine 2,3-dioxygenase (IDO) yang karenanya menyebabkan depelesi triptofan. Triptofan merupakan asam amino penting untuk biosintesis serotonin dan melatonin. Adanya sel $\mathrm{T}$ dan sel NK yang mensekresi IFN- $\gamma$ yang menginduksi aktivitas IDO sehingga triptofan hancur menjadi kinurenin/ KYN, menurunkan sintesis serotonin dan menghasilkan asam quinolinik yang bekerja pada N-methyl-D-aspartat/NMDA sehingga terjadi depresi. Triptofan penting dalam sistem imun terhadap infeksi mikroba (Haroon, Raison \& Miller, 2012).

Selain serotonin, neurotransmitter lain yang terpengaruh adalah sistem dopaminergik. Sitokin telah terbukti menurunkan produksi dopamin, hewan coba yang diberikan IFN- $\alpha$ menunjukkan konsentrasi tetrahydrobiopterin (BH4) dan dopamin dalam saraf pusat yang rendah akibat stimulasi nitrit oksida (NO). Tetrahidrobiopterin adalah ko-faktor enzim tirosin hidroksilase yang mengubah tirosin 
menjadi L-DOPA yang merupakan enzim dalam sintesis dopamin. Setelah dilakukan pengobatan dengan NO-inhibitor didapatkan peningkatan $\mathrm{BH} 4$ dan dopamin. Aktivasi mikroglia dikaitkan dengan peningkatan produksi NO, menunjukkan bahwa pengaruh sitokin pada BH4 via NO mungkin merupakan mekanisme utama dimana sitokin mengurangi ketersediaan Dopamin pada daerah otak yang tidak relevan (Lucile Capuron \& Miller, 2011).

Jalur Glutamat atau eksitotoksisitas terkena dampak ketika sitokin dan mediator inflamasi teraktivasi di dalam otak. Proses infeksi merangsang pelepasan glutamatdari sel glial dan mengurangi pengambilan glutamat lewat regulasi transporter glutamat. Pelepasan glutamat yang berlebihan oleh akses astrosit dapat mempengaruhi reseptor NMDA ekstrasinaptik dan menurunkan faktor trofik termasuk faktor neurotropik dan BNDF. Selain itu, astrosit dan mikroglia akanmelepaskan oksigen reaktif dan nitrogen spesies yang dikombinasikan dengan QUIN yang dapat memperkuat oksidatif dan menekan jenis sel neuron dan oligodendrosit yang rentan terhadap ROS. Efek hilangnya glial dan oligodendrosit pada beberapa daerah otak berhubungan dengan suasana hati, khususnya pada daerah korteks prefrontal subgenual dan amigdala dan memunculkan gejala depresi berat (Lucile Capuron \& Miller, 2011).

Terdapat model imunologi yang disebut sebagai sickness behavior yang merupakan reaksi non-spesifik terhadap infeksi dan inflamasi. Sickness behavior ditandai oleh sekumpulan gejala mirip depresi yaitu kelemahan, malaise, tidak mampu berkonsentrasi, minat menurun dan berkurangnya nafsu makan. Kesakitan ini berhubungan dengan psikopatologi selama infeksi dan inflamasi yang dimediasi oleh sitokin proinflamasi seperti IL-1, IL-6, TNF- $\alpha$, dan IFN- $\gamma$. Tingkat ansietas, kecemasan dan gangguan kognitif berhubungan dengan kadar sitokin yang bersirkulasi di darah (Müller \& Schwarz, 2007).

Inflamasi sekecil apapun dapat menjadi aktivasi depresogenik pada individu yang memiliki kerentanan fisiologis. Terdapat dua pendekatan untuk membuktikannya. Pendekatan pertama yaitu teori yang disebut immune response element amplification
(IREA). Pendekatan ini menguji pola aktivitas orang-orang sehat dengan orang-oran nonimun. Pada orang non-imun respon terhadap inflamasi lebih rendah sehingga tidak peka terhadap respon penghambatan glukokortikoid, pengurangan sinyal parasimpatis, mengurangi produksi brain-derived neurotrophic factor (BDNF), serta mengurangi volume hipokampus. Hal-hal ini menyebabkan individu lebih sensitifterhadap efek depresogenik dari inflamasi (Raison \& Miller, 2011).

Pendekatan kedua dengan orang-orang yang menggunakan terapi IFN- $\alpha$ untuk aktivasi kekebalan perubahan depresi jangka pendek dan pengobatan depresi jangka panjang. Dalam jadwal dan dosis yang sama, tiap individu mampu menghasilkan proses depresogenesis yang berbeda-beda. Fenomena dilihat setelah satu jam menerima dosis IFN- $\alpha$ pertama. Individu yang merespon dengan peningkatan pelepasan hormone kortikotropin yang diaktivasi protein kinase lebih mungkin terkena depresi selama 1 atau 2 bulan di tengah pengobatan. Sementara kelompok yang meresoin dengan sickness-type symptoms cenderung lebih lama untuk terkena depresi bahkan lebih dari 8 minggu terapi IFN- $\alpha$ (Raison \& Miller, 2011).

Toxoplasma gondii, Depresi dan Bunuh Diri Penelitian pada hewan coba yang diinduksi $T$. gondii, kemudian terbentuk kista pada system saraf pusat dan menimbulkan perubahan tingkah laku dan percepatan transmisi. Manifestasi tingkah laku berupa lambatnya waktu reaksi, pencarian hal baru, dan ketertarikan terhadap bau. Hewan coba mengalami toksoplasmosis kronis dengan kista pada sel neuron dan glial serta gangguan neurotransmitter seperti dopamin, serotonin, atau norepinefrin, dan proses inflamasi lokal di otak(Hsu, Groer \& Beckie, 2014) 


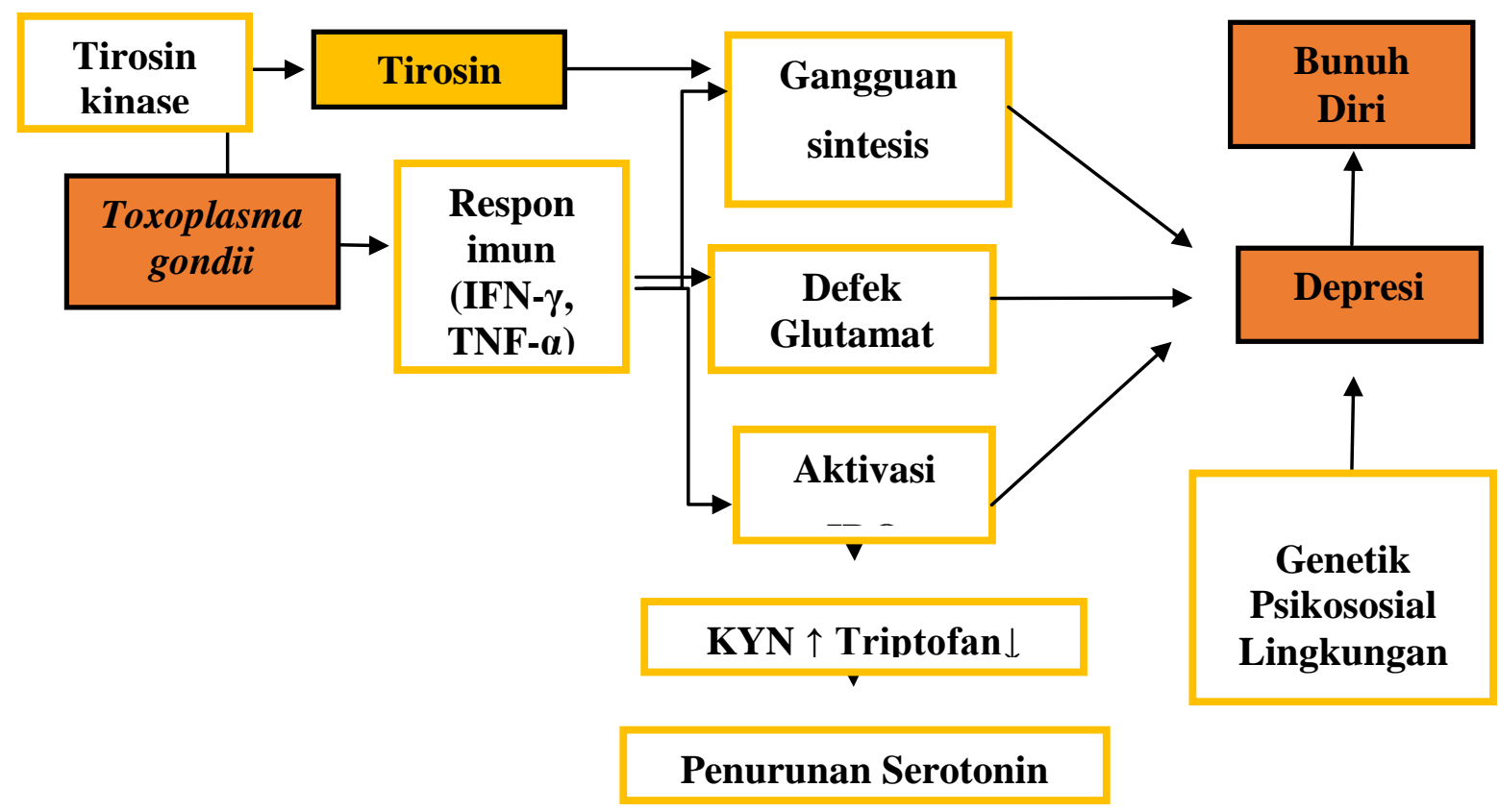

Gambar 1.

Mekanisme hubungan Toksoplasmosis dan kejadian bunuh diri dan depresi(Hsu, Groer \& Beckie, 2014)

Terdapat hubungan antar bunuh diri dan infeksi T. gondii. Penderita gangguan mood dengan riwayat percobaan bunuh diri memiliki titer anti-toksoplasma yang lebih tinggi dibanding penderita yang tidak bunuh diri. Demikian pula pada gangguan jiwa lain, pasien yang menerima pengobatan skizofrenia, gangguan bipolar dan depresi berat yang memiliki peningkatan IgM dan IgG (untuk rawat jalan) anti-toksoplasma yang tinggi lebih berpeluang untuk bunuh diri dibanding kelompok kontrol.(Arling et al., 2009)

Bunuh diri pada penderita toksoplasmosis laten kemungkinan besar diakibatkan oleh gejala psikosis seperti skizofrenia ataupun gangguan bipolar. Dopamin memainkan peran besar dalam patofisiologi gejala psikosi, di mana dopamin dilepas dalam jumlah besar pada nukleus accumbens dan mengaktifkan daerah retrohipokampal serta mengganggu daerah forniks korteks frontal otak yang memproses emosi dan pengambilan keputusan. Pada individu yang sehat, kekurangan dopamin dapat menimbulkan gejala psikosis namun aktivasi dopaminergik yang berlebihan akibat toksoplasmosis laten dalam jangka panjang mampu menginduksi degenerasi neuron sistem dopamin dan menyebabkan keadaan hipodopaminergik dan berujung pada gejala psikotik.(Zhu, 2009)

Merupakan hal yang masuk akal bila toksoplasmosis dapat meningkatkan kadar dopamin karena Toxoplasma gondii memiliki enzim tirosin kinase yang berperan dalam suplai tirosin untuk protein kinase. Jika kadar tirosin sudah terlalu tinggi, tirosin akan dikonversi menjadi L-DOPA. Dimana LDOPA sendiri merupakan prekursor untuk neurotransmiter dopamin. Fungsi sebenarnya dari enzim tirosin kinase pada $T$. gondii masih tidak jelas. Namun yang pasti adanya kista jaringan pada otak akan terus-menerus menghasilkan tirosin kinase dan mengkatalisis fenilalanin menjadi tirosin untuk diubah menjadi L-DOPA.(Gaskell et al., 2009)

Depresi pada penderita toksoplasmosis dapat disebabkan oleh inhibisi pertumbuhan parasit dengan kelaparan triptofan. Hal ini dapat menjadi alasan peningkatan resiko bunuh diri pada pasien psikiatrik dengan konsentrasi tinggi antibodi anti-Toxoplasma. Data terkait peningkatan prevalensi toksoplasmosis pada pasien percobaan bunuh diri di Eropa. (Flegr, 2013). Respon imun pada infeksi $T$. gondimampu mengeksaserbasi faktor resiko bunuh diri seperti prekursor potensial depresi 
dan defisit kognitif. Infeksi toksoplamosis menghasilkan sitokin proinflamasi seperti interleukin-6 (IL-6) pada cairan serebrospinal serta Tumor Nekrosis Faktor dalam plasma yang berhubungan dengan perilaku bunuh diri. (Ling et al., 2011) Selain itu aktivasi sel $\mathrm{T}$ helper yang mensekresi IFN- $\gamma$ untuk memblok pertumbuhan $T$. gondii dan sekaligus menginduksi aktivasi enzim IDO sehingga produksi serotonin otak berkurang dan timbullah depresi.

\section{SIMPULAN}

Toksoplasmosis kronis yang disebabkan ookista dalam sistem saraf pusat mampu menyebabkan perubahan psikiatris. Inflamasi akibat hadirnya sel radang dan sitokin proinflamasi menyebabkan penurunan triptofan, asam amino penyusun serotonin dan juga penurunan dopamin. Inflamasi juga menyebabkan pelepasan glutamate secara berlebihan dan pelepasan bahan oksidatif oleh mikroglia sehingga sel glial dan sel neuron yang berada pada korteks prefrontal serta amigdala rusak. Proses ini yang memunculkan gejala depresi baik minor maupun mayor pada penderita toksoplasmosis. Depresi mayor merupakan faktor resiko dan tanda bahaya pada bunuh diri.

\section{DAFTAR PUSTAKA}

Alvarado-Esquivel, C.,Sánchez-Anguiano, LF., Arnaud-Gil, CA., LópezLongoria, JC., Molina-Espinoza, LF., Estrada-Martínez, S., et al. 2013. Toxoplasma gondii infection and suicide attempts: A case-control study in psychiatric outpatients. Journal of Nervous and Mental Disease. 201(11):948-52. doi: 10.1097/NMD.0000000000000037.

Arling, T A., Yolken, RH., Lapidus, M., Langenberg, P., Dickerson, FB., Zimmerman, SA.,et al. 2009. Toxoplasma gondii antibody titers and history of suicide attempts in patients with recurrent mood disorders. Journal of Nervous and Mental Disease. 197(12):905-8. doi: 10.1097/NMD.0b013e3181c29a23.

Carruthers, V. B. dan Suzuki, Y. 2007. Effects of Toxoplasma gondii infection on the brain. Schizophrenia 33(3):745-51. Bulletin. 10.1093/schbul/sbm008.
CDC. 2018. Preventing Suicide 2018 What is suicide? (8255):1-2.

Dickerson, F., Wilcox, HC., Adamos, M., Katsafanas, E., Khushalani, S., Origoni, A.,et al. 2017. Suicide attempts and markers of immune response in individuals with serious mental illness.Journal of Psychiatric Research. Elsevier Ltd, 87(2017):3743.doi: 10.1016/j.jpsychires.2016.11.011.

Dubey, J. P. 2009. History of the discovery of the life cycle of Toxoplasma gondii.International Journal for Parasitology. Aust Soc for Parasit Inc. 39(8):877-82. doi: 10.1016/j.ijpara.2009.01.005.

Elvira, S. D. dan Hadisukanto, G. 2014. Buku Ajar Psikiatri. Edisi ke-2. Jakarta: Badan Penerbit FKUI.

Fekadu, A., Shibre, T. dan Cleare, A. J. 2010. Toxoplasmosis as a cause for behaviour disorders - Overview of evidence and mechanisms. Folia Parasitologica. 57(2):105-13.doi: 10.14411/fp.2010.013.

Flegr, J. 2013. How and why Toxoplasma makes us crazy. Trends in Parasitology. Elsevier Ltd. 29(4):15663.doi: 10.1016/j.pt.2013.01.007.

Gaskell, EA., Smith, JE., Pinney, JW., Westhead, DR., McConkey, GA. 2009. A unique dual activity amino acid hydroxylase in Toxoplasma gondii.PLoS ONE. 4(3):1-10.doi: 10.1371/journal.pone.0004801.

Hadidjaja, P. dan Margono, S. 2013. Dasar Parasitologi Klinik. Edisi Pertama. Jakarta.FKUI.

Haroon, E., Raison, C. L. dan Miller, A. H. 2012. Psychoneuroimmunology meets neuropsychopharmacology:

Translational implications of the impact of inflammation on behavior. Neuropsychopharmacology. Nature Publishing Group. 37(1):137-62.doi: 10.1038/npp.2011.205.

Hsu, P. C., Groer, M. dan Beckie, T. 2014. New findings: Depression, suicide, 
and Toxoplasma gondii infection. Journal of the American Association of Nurse Practitioners.26(11):629-37. doi: $10.1002 / 2327-6924.12129$.

Kasper, DL., Fauci, AS., Hauser, SL., Longo, DL., Jameson, JL., Loscalzo, J. 2015. Harrison's Principles of Internal Medicine. Journal of Chemical Information and Modeling, II(9):1689-99. doi: 10.1017/CBO9781107415324.004.

Ling, V.J., Lester, D., Mortensen, PB., Langenberg, PW., Postolache, TT.2011. Toxoplasma gondii seropositivity and suicide rates in women.Journal of Nervous and Mental Disease. 199(7):440-4. doi: 10.1097/NMD.0b013e318221416e.

Liu, Q., Ze-dong, W., Si-yang, H., Xing-quan, Z. 2015. Diagnosis of toxoplasmosis and typing of Toxoplasma gondii. Parasit \& Vec. 1:1-14. doi: 10.1186/s13071-015-0902-6.

Lucile Capuron dan Miller, A. H. 2011. Immune System to Brain Signaling. Pharmacology \& Theraputics. 130(2):226-38. doi: 10.1016/j.pharmthera.2011.01.014.Im mune.

Maldonado, YA., Read, JS., Byington, CL., Barnett, ED., Davies, HD., Edwards, KM.,et al. 2017. Diagnosis, treatment, and prevention of congenital toxoplasmosis in the United States. Pediatrics. 139(2). doi: 10.1542/peds.2016-3860.

Maramis, W. F. dan Maramis, A. F. 2009.Catatan Ilmu Kedokteran Jiwa. Edisi 2. Surabaya: Airlangga University Press.

Maslim, R. 2013.Buku Saku Diagnosis Gangguan Jiwa. Jakarta: Bagian Ilmu Kedokteran Jiwa FK Unka Atma Jaya.

Müller, N. dan Schwarz, M. J. 2007. The immune-mediated alteration of serotonin and glutamate: Towards an integrated view of depression.Molecular Psychiatry. 12(11):988-1000.doi: 10.1038/sj.mp.4002006.

Pjevac, M. dan Pregelj, P. 2012. Neurobiology of suicidal behaviour. Psychiatria Danubina. 24(SUPPL.3):336-41.doi: 10.1038/nrn1220.

Raison, C. L. dan Miller, A. H. 2011. Is Depression an Inflammatory Disorder? Curr Psychiatry. 13(6):14. doi:

10.1109/ICCEREC.2016.7814953.

Roberts, L. S. dan Janovy Jr, J. 2009. Gerald D. Schmidt \& Larry S. Roberts' Foundations of Parasitology. Boston. McGraw Hills

Soleimani, L., Lapidus, K. A. B. dan Iosifescu, D. V. 2011. Diagnosis and Treatment of Major Depressive Disorder.Neurologic Clinics. 29(1):177-93. doi: 10.1016/j.ncl.2010.10.010.

Stone, D., Holland, K., Bartholow, B., Crosby, A., Davis, S., Wilkins, N. 2017. Preventing Suicide: A Technical Package of Policy, Programs, and Practices. CDC

Zhu, S. 2009. Psychosis may be associated with toxoplasmosis.Medical Hypotheses. Elsevier Ltd. 73(5):799- 